\title{
Description of a new sepioline species, Sepiola bursadhaesa n. sp. (Cephalopoda: Sepiolidae), from the Catalan Sea, with remarks and identification key for the Sepiola atlantica group
}

\author{
GIAMBATTISTA BELLO \\ Arion, Via Colombo 34, 70042 Mola di Bari, Italia. E-mail: giamb.bello@ gmail.com
}

\begin{abstract}
SUMMARY: Diversity among members of the genus Sepiola (Cephalopoda: Sepiolidae) in the NE Atlantic-Mediterranean area is fairly high; 10 species have been recorded. In this paper, a new species, Sepiola bursadhaesa n. sp., is described based on ten specimens from the Catalan Sea. They are lodged in the Museo Nacional de Ciencias Naturales of Madrid. The new species is compared with the closely related species Sepiola affinis Naef, 1912 and Sepiola intermedia Naef, 1912, the latter of which is possibly its sister species. Male Sepiola bursadhaesa n. sp. differs from Sepiola intermedia in having a very wrinkled and outward projecting tubercle on the copulatory apparatus, and the first three (rather than two) suckers of the dorsal row of the distal part of the hectocotylus enlarged. The middle sucker of the three suckers is the largest. In female S. bursadhaesa n. sp., unlike all other species in the genus, the bursa copulatrix is fused throughout its posterior rim to the inner side of the mantle. The relationships between the species of the Sepiola atlantica group sensu Naef (1923), to which $S$. bursadhaesa $\mathrm{n}$. sp. belongs, are described. An identification key for this group is provided.
\end{abstract}

Keywords: Cephalopoda, Sepiolidae, Sepiola, new species, diversity, Mediterranean Sea, Atlantic Ocean.

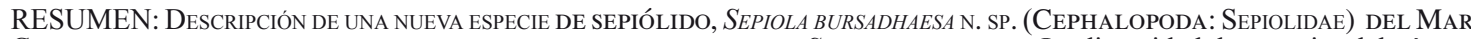

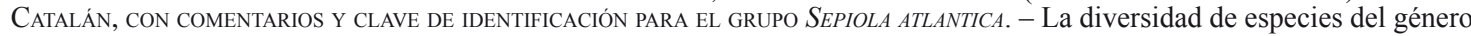
Sepiola (Cephalopoda: Sepiolidae) en la zona NE del Atlántico-Mediterráneo es bastante elevada, habiéndose registrado un total de 10 especies. En este artículo, una nueva especie, Sepiola bursadhaesa n. sp., se describe en base a 10 ejemplares del Mar Catalán. Los ejemplares se hallan depositados en el Museo Nacional de Ciencias Naturales de Madrid. La nueva especie se compara con la especie estrechamente relacionada Sepiola affinis Naef, 1912 y Sepiola intermedia Naef de 1912, siendo ésta última posiblemente una especie muy similar. El macho de Sepiola bursadhaesa n. sp. difiere de Sepiola intermedia por poseer un tubérculo rugoso y sobresaliente en el organo copulatorio, y mostrar agrandadas las tres primeras (en lugar de dos) ventosas dorsales de la zona distal del hectocótilo. La ventosa media de las tres ventosas es la mayor. A diferencia de otras especies del mismo género, en las hembras de S. bursadhaesa n. sp., la bolsa copulatoria se fusiona a lo largo de su borde posterior con la zona interior del manto. Se describen las relaciones entre las especies pertenecientes al grupo de Sepiola atlantica sensu Naef (1923), al que pertenece S. bursadhaesa n. sp. Así mismo se proporciona una clave de identificación para este grupo.

Palabras clave: Cephalopoda, Sepiolidae, Sepiola, nueva especie, diversidad, Mar Mediterráneo, Océano Atlántico.

\section{INTRODUCTION}

The subfamily Sepiolinae Leach, 1817 (Cephalopoda: Sepiolidae) is represented in the NE Atlantic-Mediterranean region by three genera: Sepiola Leach, 1817, Sepietta Naef, 1912 and Rondeletiola Naef, 1921. Sepiola is the most speciose; 10 species are reported from this region: Sepiola affinis Naef, 1912, Sepiola atlantica d'Orbigny, 1842, Sepiola aurantiaca, Jatta, 1896, Sepiola intermedia Naef, 1912, Sepiola ligulata Naef, 1912, Sepiola pfefferi Grimpe, 1921, Sepiola robusta Naef, 1912, Sepiola rondeletii Leach, 1817, Sepiola steenstrupiana Levy, 1912 and Sepiola tridens de Heij and Goud, 2010 (cf. Reid and Jereb 2005, Groenenberg 
et al. 2009, de Heij and Goud 2010). Four sepiolines from the Indo-Pacific and one from the western African coast have also been ascribed to the genus Sepiola (Reid and Jereb 2005).

While examining the cephalopod collection of the Museo Nacional de Ciencias Naturales in Madrid (MNCN), I found a sepioline sample among the historical collection labelled "Sepiola rondeleti Leach, 1817". Examination of the animals in this sample showed that they do not belong to Sepiola rondeletii but to two different species. One specimen is a male of Sepietta obscura Naef, 1916; 10 specimens $(4+q$ and $\left.6 \lambda \partial^{\lambda}\right)$, all of them pertaining to the genus Sepiola, display characters that set them apart from all the known species in this genus. Based on these specimens, the new species, Sepiola bursadhaesa n. sp., is described and compared with closely related species of the Sepiola atlantica group, as defined by Naef (1923), to which it belongs. A reappraisal of this group is carried out in order to understand the relationships among its members. An identification key for this group is provided.

\section{MATERIALS AND METHODS}

The material upon which Sepiola bursadhaesa n. sp. is described is housed in the MNCN of Madrid (sample no. 15.06/226) and is part of the historical collection. The original, i.e. historical, label in the glass jar reports the following words "Sepiola Rondeletii Leach / Vulg. Morralet [= common name dwarf bobtail squid] / Mercado de Barcelona [= Barcelona market]". Thus, the information about this sample is quite scanty. According to the former curator of the molluscan collection of the MNCN, these sepiolines were collected in the first half of the 1930s (Oscar Soriano pers. comm.). The modern label reports the presence of 13 specimens (" 13 ejemplares") in the sample, but only 12 specimens were found in the jar when I first examined it; one of them lacked the arm-tentacle crown, which evidently had been cut away. As reported in the Introduction, one specimen (mature male, $\mathrm{ML}=22 \mathrm{~mm}$ ) was identified as Sepietta obscura; 10 others belong to a new Sepiola species, which is described herein, and represents the species type material. The mutilated specimen, a mature male ( $\mathrm{ML}=21 \mathrm{~mm})$, is also a member of the genus Sepiola, but the lack of arms and tentacles makes accurate identification impossible.

The complete animals in the sample were in fairly good condition, apart from the fact that several arm suckers had fallen off in some specimens and that the majority of tentacular clubs had lost most of their suckers. All the females and some males in the sample had their mantle already cut open, as is customary when sepiolines are examined in order to expose the mantle cavity organs. The chromatophores had faded to some extent because of the prolonged storage of the specimens in ethyl alcohol.

The photographs of anatomical details were taken with a digital camera (DFC 420, Leica, Cambridge, U.K.) attached to a stereomicroscope.

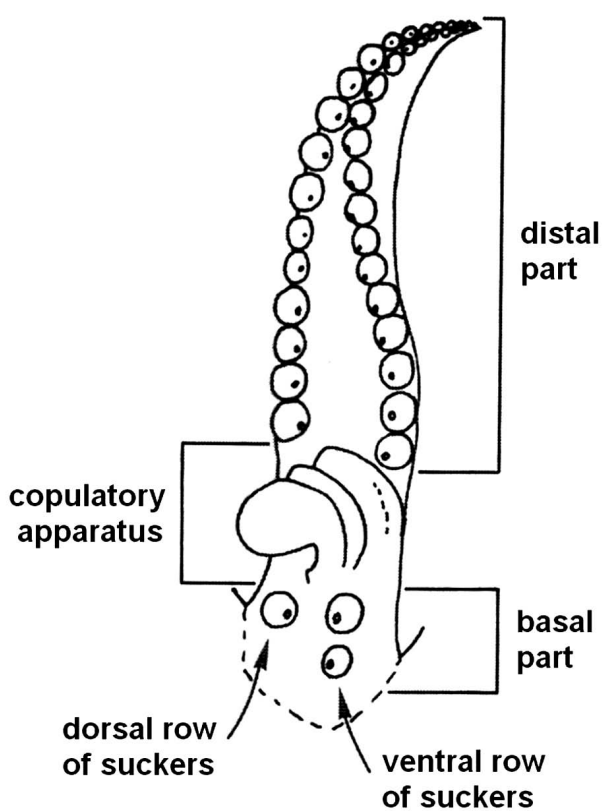

FIG. 1. - Schematic rendering of the general Sepiola hectocotylus (the basic type of the Sepiola atlantica group is depicted here) (after Bello 1995).

Abbreviations used: ML, dorsal mantle length; VML, ventral mantle length; TL, total length; I to IV, first to fourth pair of arms, viz. dorsal, dorso-lateral, ventro-lateral, ventral arms, respectively; GL, gladius length.

Tissue samples from three specimens were used for a tentative genomic DNA isolation and subsequent amplification of cytochrome oxidase subunit I (COI) fragments (Folmer et al. 1994) (analyses performed at the Department of Invertebrate Zoology and Functional Histology - Kazan Federal University, Russia). No suitable results were obtained because of the poor quality of samples, which was attributed to their longterm storage in formalin before they were stored in ethyl alcohol.

\section{RESULTS}

\author{
Class CEPHALOPODA \\ Subclass COLEOIDEA \\ Order SEPIOLIDA
}

Family SEPIOLIDAE Leach, 1817

Subfamily Sepiolinae Leach, 1817

Genus Sepiola Leach, 1817

Sepiola Leach, 1817: 137. Type species Sepiola rondeletii Leach, 1817 by monotypy.

Diagnosis. Sepiolines with pair of internal kidneyshaped light organs on ventral surface of ink sac; suckers biserial on arms I to III and at least proximally on arms IV; tentacle club suckers in four to eight oblique rows; females with ear-shaped bursa copulatrix on left ventral side of mantle cavity; males with left arm 
I hectocotylized: suckers and sucker stalks typically arranged in a basal part, a copulatory apparatus comprised of modified suckerless stalks, and a distal part (cf. Bello 1995) (Fig. 1).

\section{Sepiola bursadhaesa n. sp. (Figs 2-11; Table 1)}

Type material. Holotype: MNCN 15.06/226H, female, 18 mm ML, Barcelona fish market (Spain). Paratypes: MNCN 15.06/226P1 to 15.06/226P9, 3 females and 6 males, 15-24 ML, Barcelona fish market (Spain).

Diagnosis. Sepiola with biserial suckers on all arms, including tips of arms IV; ventral margin of mantle slightly sinuate, with low rounded projection on each side of funnel; tentacle clubs with six oblique rows of suckers, those of two dorsal rows and some in middle of third row larger than others; bursa copulatrix small and ear-shaped, posterior rim fused throughout its length to inner side of mantle; hectocotylus not evidently curved with three regular equal-sized suckers in basal part, copulatory apparatus typical, dorsal tubercle very wrinkled, projecting outward, distal part with dorso-lateral groove on inner side, first three suckers of dorsal row enlarged and incomplete circular groove perpendicular to arm axis separating distalmost third of arm from proximal part.

Description. Large Sepiola with mantle lengths equal in fully mature specimens of both sexes (maximum recorded $\mathrm{ML}=24 \mathrm{~mm}$ ). Maximum recorded TL, without tentacles, about $56 \mathrm{~mm}$ in a male (arms are variously curled up in all specimens); TL slightly longer in males than females. Tentacles exceed TL by 10-20 $\mathrm{mm}$.

Body shape corresponds to general shape of $\mathrm{NE}$ Atlantic-Mediterranean Sepiola species. Mantle sacshaped, broadly rounded at posterior end, its length exceeding its width, outline U-shaped (Fig. 2). Dorsal mantle margin fused to head by cutaneous occipital band (occipital commissure) of about $20 \%$ of mantle width. Ventral mantle margin slightly sinuate, notched around funnel, with low rounded projection on either side. VML about 1-3 mm shorter than ML. Fins typical for Sepiola, each inserted midway along sides of mantle, broadly rounded; fin length slightly exceeds half ML, insertion line about half overall fin length. Head width slightly smaller than mantle width, 70.8 to $84.2 \% \mathrm{ML}$ (mean=76.2\%) in males and 62.5 to $86.7 \%$ ML (mean $=72.4 \%)$ in females; comparatively smaller than ML in fully mature specimens (probably due to the relative increase in mantle size because of gonad development that is more marked in females). Eyes large, bulging beyond sides of the head and covered by corneal membrane. Funnel long, $86 \%$ to $89 \%$ ML, covered basally by ventral margin of mantle, funnel free length $c a$. 57\% ML; distal end exceeds junction of ventral arms.

Arm formula II=III $>$ IV $>$ I in both sexes. Arms longer in males than in females (see sexual dimorphism in

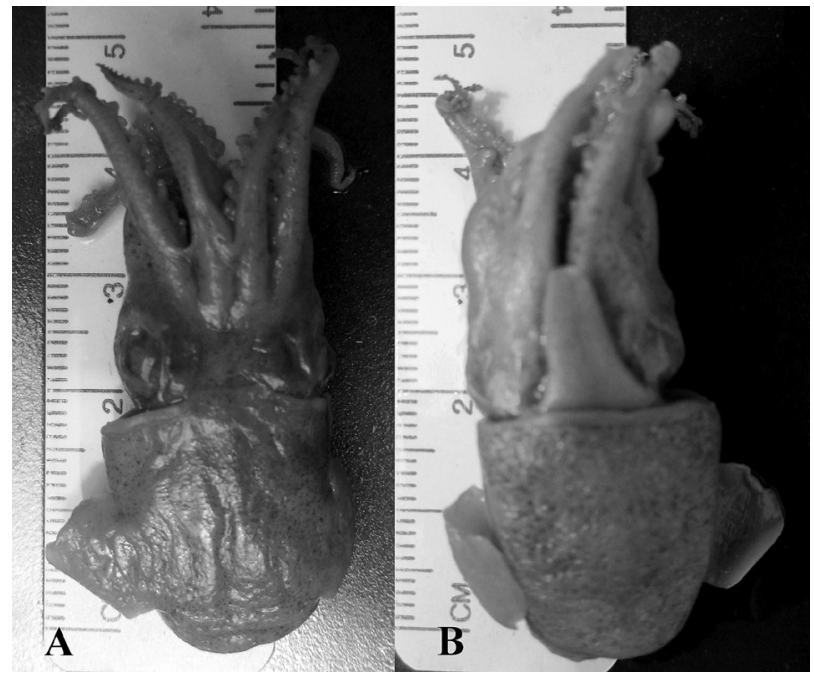

FIG. 2. - Sepiola bursadhaesa n. sp., paratype, MNCN 15.06/226P8, male. A, dorsal view; B, ventral view.

TL, above). Suckers stalked, alternately placed in two series on oral side of all arms, including distalmost part of arms IV. Brachial crown of mature males displays some features not seen in females. In addition to left arm I hectocotylization (see below for its detailed description), proximal half of arms III much more robust than remaining arms and strongly bent inward (a character described in several Sepiola species), and distal half normally thin; arms II bear some enlarged suckers towards arm tip; arms IV bear some enlarged suckers in middle third; sucker stalks of enlarged suckers on arms II and IV slightly longer and larger than remaining stalks. Arm web reduced; encloses base of tentacles between arms III and IV.

Tentacles thin and delicate. Tentacular club longitudinally lined by well-developed protective membranes dorsally and ventrally. Club tapers abruptly distally, elongate. Club suckers in six oblique rows; those of two dorsal rows larger than other suckers; a few suckers of third row (counting from dorsal one) also enlarged in middle part of row.

Overall skin colouration pale reddish brown; most chromatophores not expanded. (Actual colouration undoubtedly altered by many year storage in ethyl alcohol.) No particular chromatophore distribution pattern observed, apart from a row of chromatophores dorsally lining tentacular shaft of club, close to protective dorsal membrane.

Mantle-locking apparatus straight, as typical for the genus.

Gladius positioned sagittally on inner face of dorsal mantle, encased in shell sac (see Bizikov (2008) for general description of sepiolid gladius). Gladius reduced, posterior tip does not reach posterior end of mantle (as is typical for the genus) but extends from anterior mantle margin to about $40 \%$ of ML. Chitinous rachis tan-coloured, widely open $\mathrm{V}$-shaped in cross section. Gladius bluntly pointed at anterior extremity then gradually enlarges to reach width of about $1 / 20$ 


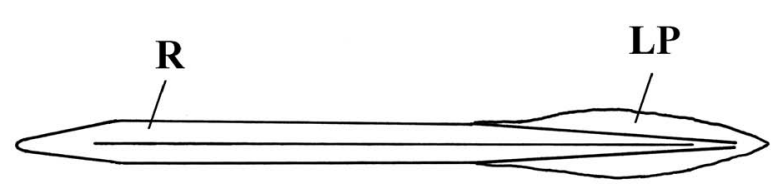

FIG. 3. - Diagram of Sepiola bursadhaesa n. sp. gladius (anterior extremity on the left). R, rachis; LP, lateral plate.

GL (0.4 $\mathrm{mm}$ in examined specimen); posteriorly, two sides of rachis run almost parallel to about $2 / 3$ of GL and subsequently converge to a point short of posterior end (Fig. 3). Point where rachis starts to narrow corresponds to anterior insertion of thin and transparent lateral plates, which progressively widen to slightly less than $1 / 10$ of GL at their widest point $(0.7 \mathrm{~mm}$ in examined specimen) and then taper posteriorly. Posterior third of gladius spear-head shaped where rachis is the shaft and lateral plates the two lateral blades.

Beak indistinguishable from that of other NE Atlantic-Mediterranean Sepiola species (cf. Clarke 1986). Lower beak with blunt tip; jaw edge profile convex, jaw angle indistinct. Wing makes a comparatively high fold that slightly obscures jaw angle. Lateral wall without fold, roughly rectangular with lower edge slightly convex, corner faintly produced.

Radula typical of the genus (cf. Naef 1923); each row bears seven unicuspid teeth, according to formula $1+2+1+2+1$.

The mantle cavity of males does not show any unique traits that allows them to be distinguished from other Sepiola species.

Female bursa copulatrix small, roughly ear-shaped, slightly longer than wide; folds converge towards center of bursa where they deepen into a roundish opening (Figs 4-6). Bursa occupies about one half (or less in

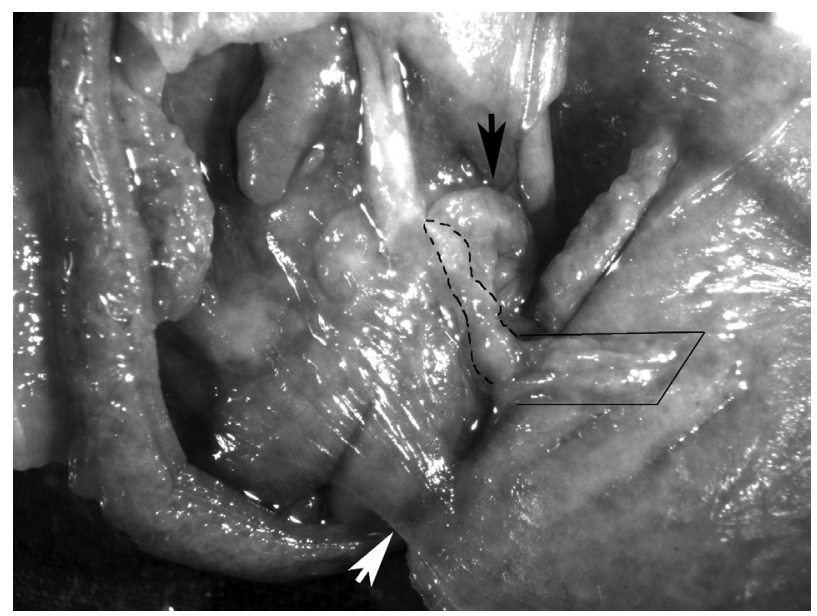

FIG. 4. - Mantle cavity of Sepiola bursadhaesa n. sp., holotype, MNCN 15.06/226H, female. The white arrow points to the border of the velum, the black arrow indicates the bursa copulatrix, the solid line encompasses the rearmost strip of the bursa copulatrix that broke off and remained attached to the inner mantle wall, following the cutting and turning open of the mantle ventral side; the broken line surrounds the scar left on the bursa copulatrix.

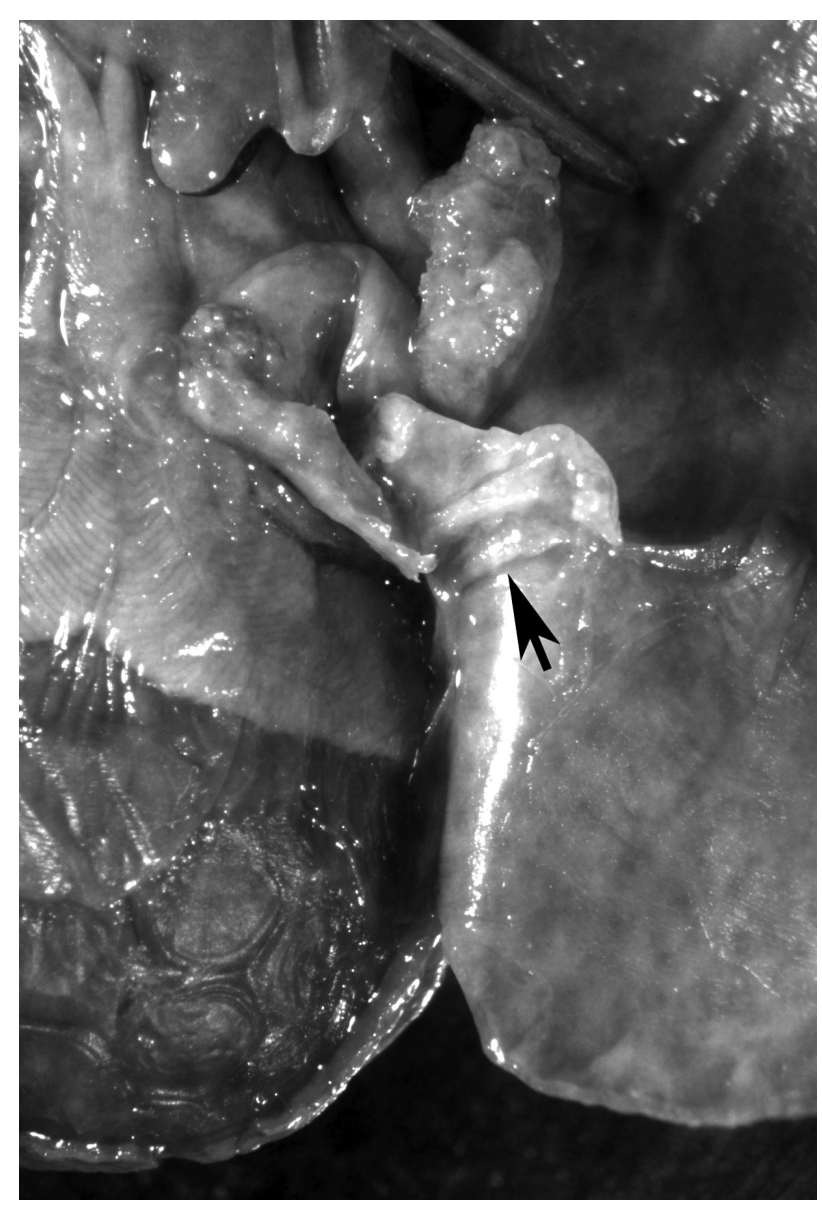

FIG. 5. - Left side of the mantle cavity of Sepiola bursadhaesa $\mathrm{n}$. sp., paratype, MNCN 15.06/226P1, female. The arrow points to the line of fusion between the bursa copulatrix and the inner wall of the mantle; above it there is a shredded strip of the bursa. Mature eggs are visible in the posterior half of the mantle cavity.

mature females) of mantle cavity length; anteriorly does not reach renal papilla; posteriorly distant from posterior end of mantle cavity; medially barely reaches sagittal mantle cavity septum. Entire posterior rim of bursa copulatrix fused to inner surface of mantle, posterior to gill septum. Scar of bursa attachment clearly visible on left inner face of mantle, crossing it transversely. Bursa copulatrix does not contract following copulation, as typical for the genus.

Distal to bursa, posterior part of ventral surface of mantle organs in females covered by thin and transparent velum (Fig. 4).

Mature oocytes, i.e. "smooth eggs", ovoid in shape. $3 \mathrm{~mm}$ long (Fig. 5).

Left arm I of mature males hectocotylized. Hectocotylus either slightly shorter or slightly longer than right arm I. Basal part bears three equal-sized, not markedly enlarged, suckers, two in ventral and one in dorsal row (Fig. 7) (refer to Figure 1 for a diagram of the general Sepiola hectocotylus structure). Copulatory apparatus typical: formed by fusion of four suckerless stalks, elongated and curved inward, ventralmost ones corresponding to third and fourth stalks of ventral row, 
dorsalmost ones probably deriving from the second and third stalks of dorsal row (to left of base of copulatory apparatus of some specimens, there is a very small knob, possibly a much reduced suckerless stalk, which might

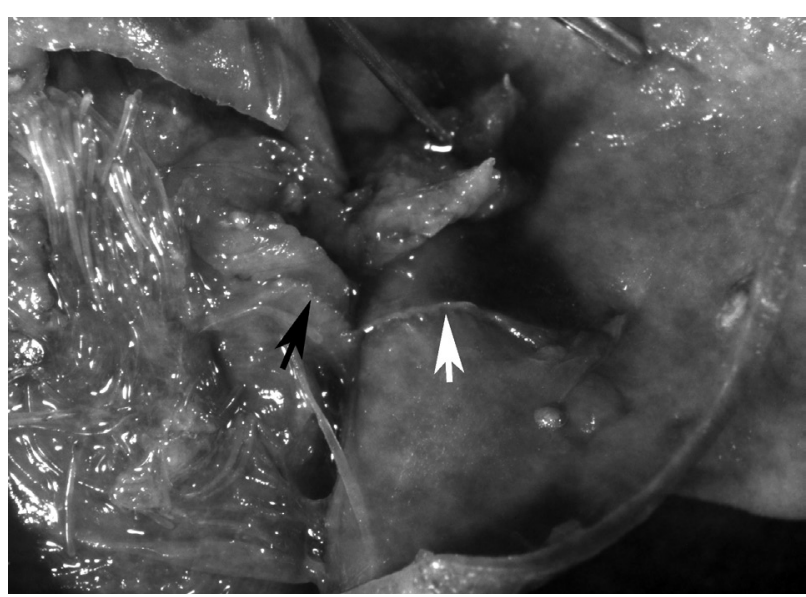

Fig. 6. - Left side of the mantle cavity of Sepiola bursadhaesa n. sp., paratype, MNCN 15.06/226P2, female. The black arrow indicates the shredded line of fusion of the bursa copulatrix to the inner mantle wall; the white arrow points to the scar of the fusion remaining on the inner mantle wall. Note the very numerous spermatophores in the mantle cavity and several spermatangia, some of the latter implanted on the bursa copulatrix. The velum is also visible.

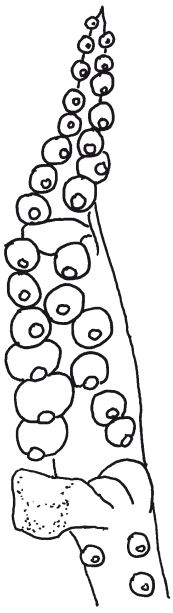

A

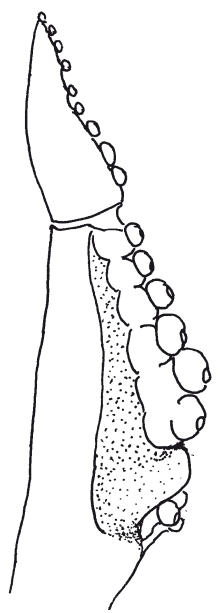

B
FIG. 7. - Diagram of Sepiola bursadhaesa n. sp. hectocotylus (left arm I of mature male). A, oral view; B, inner lateral view. be the actual second one). Dorsalmost stalks modified into comparatively large and very wrinkled tubercle that projects free away from arm; tubercle variable in shape (Figs 7 and 8). Hectocotylus slightly constricted at level

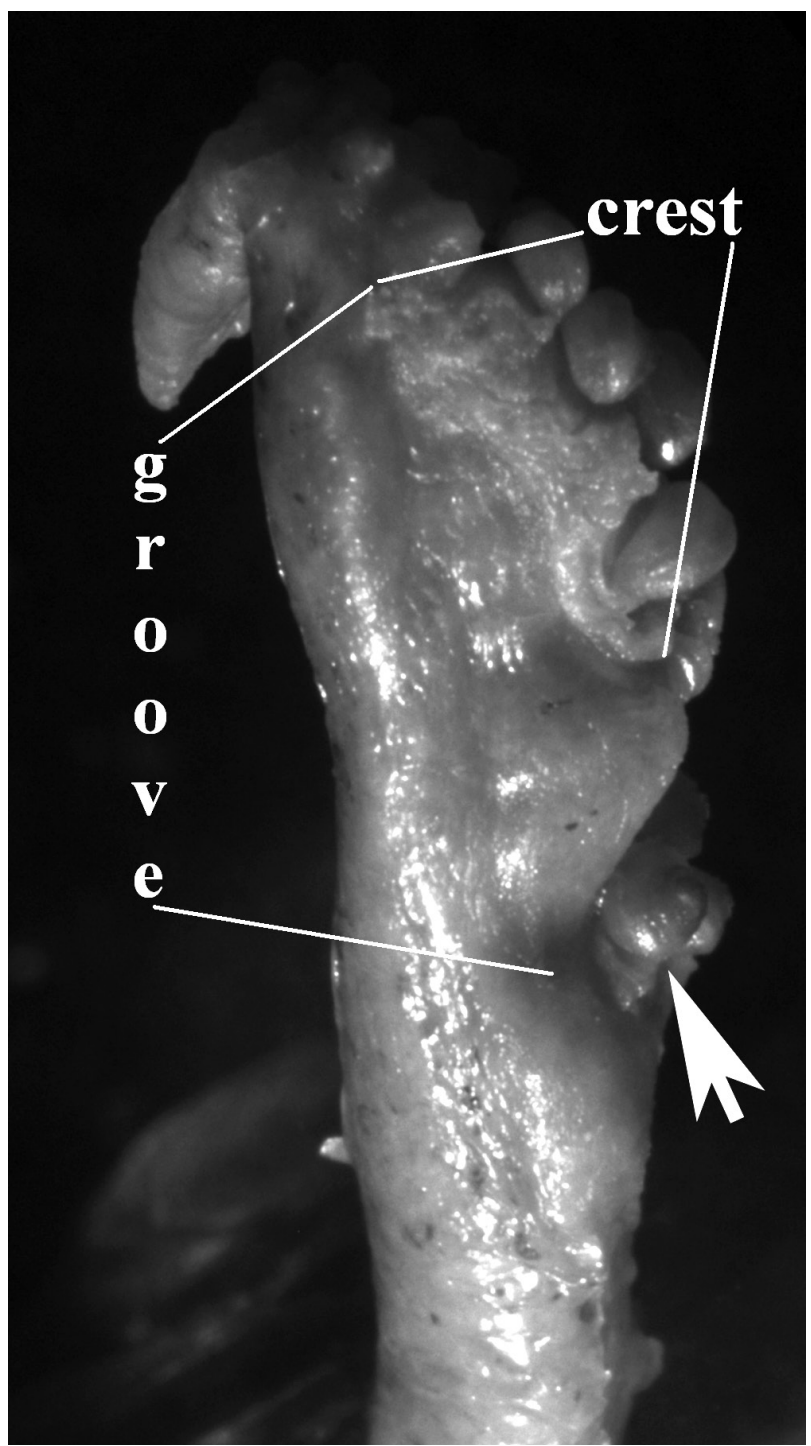

FIG. 9. - Inner lateral view of the hectocotylus of Sepiola bursadhaesa n. sp., paratype, MNCN 15.06/226P9, male. The span of the lateral groove and that of the crest bordering it orally are indicated; an arrow points to the dorsal basal sucker. (Distally the arm is artificially bent at the level of the semi-circular groove perpendicular to the arm axis; see Fig. 10.)

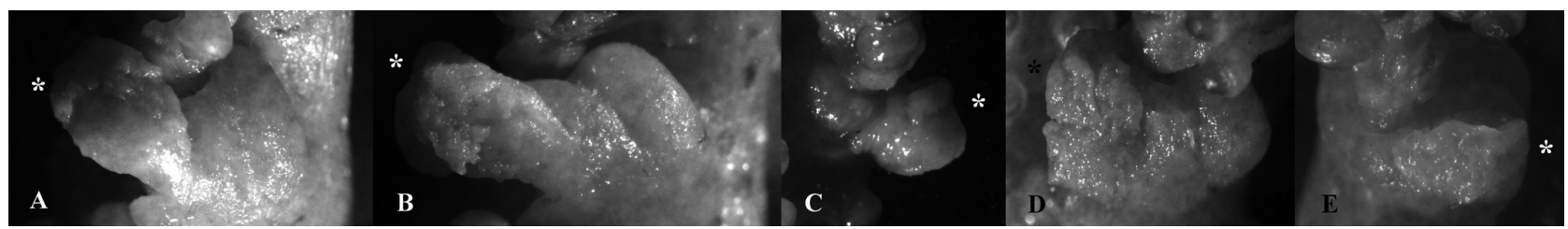

FIG. 8. - Shape variations of the dorsal tubercle of Sepiola bursadhaesa n. sp. male copulatory apparatus. An asterisk (*) marks the tubercle. A to E correspond to paratypes MNCN 15.06/226P4, 15.06/226P5, 15.06/226P6, 15.06/226P8 and 15.06/226P9, respectively. A, B and D, copulatory apparatus viewed from the oral-outer lateral side; $\mathrm{C}$, copulatory apparatus viewed from the inner lateral side (only the tubercle is visible); E, copulatory apparatus viewed from the oral side (the ventral row stalks are in shadow). 


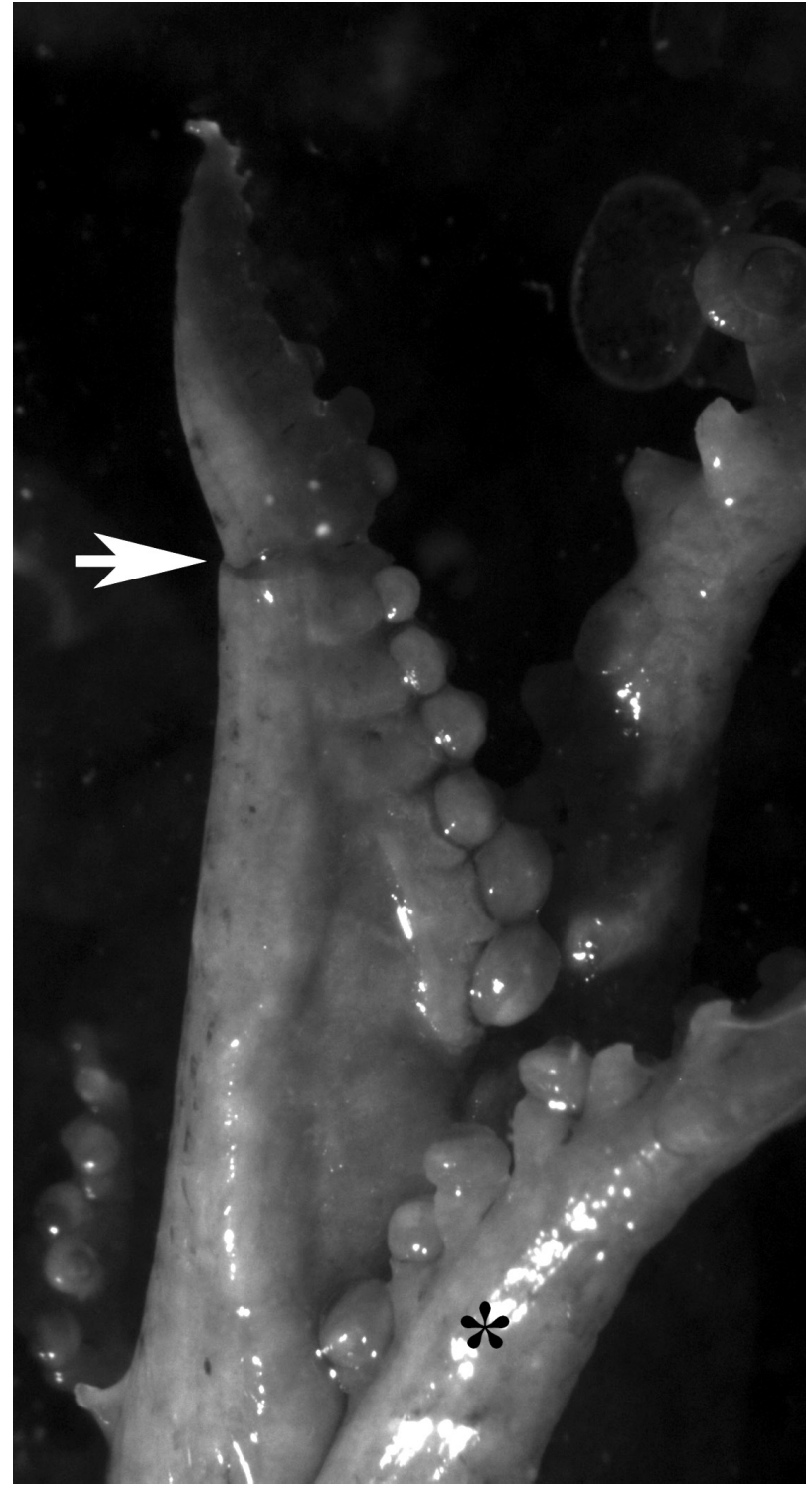

Fig. 10. - Inner lateral view of the hectocotylus of Sepiola bursadhaesa n. sp., paratype, MNCN 15.06/226P8, male. The arrow points to the semi-circular groove perpendicular to the arm axis separating the distalmost part of the hectocotylus from its proximal part, at the level of the lateral groove distal end. The six-sucker crest bordering the lateral groove is clearly visible. Note also how some proximal suckers of the dorsal row of right arm I (marked with an asterisk) fit into the hectocotylus lateral groove.

of copulatory apparatus (i.e. between basal part and distal part). Distal part of hectocotylus not manifestly bent, narrow (i.e. two rows of suckers not spread apart to form a spoon-like widening). Apex of this arm blunt. Deep and wide groove on hectocotylus lateral side facing right arm I, originating at level of basal dorsal sucker stalk, tapering towards junction of middle third and distal third of arm (Fig. 9); several suckers of dorsal row of right arm I fit into hectocotylus groove (Fig. 10). Sucker stalks, six in number, of dorsal row that border groove orally are elongated and form a sort of crest (Figs 9 and 10). Terminal part of hectocotylus, distal to groove, separated from proximal part of arm by shallow and thin incomplete circular groove around oral, inner lateral and aboral sides of arm, perpendicular to longitudinal arm axis (Fig. 10). First three suckers of dorsal row in distal part markedly enlarged with respect to following ones (Fig. 11). Second sucker largest; third one second largest; first one similar in size to third one or slightly smaller. (In a couple of males, fourth or fourth and fifth suckers also slightly enlarged.) Distal to enlarged suckers, all remaining suckers gradually taper to arm tip. Distal part of hectocotylus with 14 to 16 suckers in dorsal row. Suckers of ventral row regularly sized. Sea.

Type locality. Catalan Sea, western Mediterranean

Etymology. Bursa, purse (late Latin) + adhaesa, adhering $($ Latin $)=$ "with the bursa adhering", with reference to the bursa copulatrix posteriorly fused with the inner mantle wall.

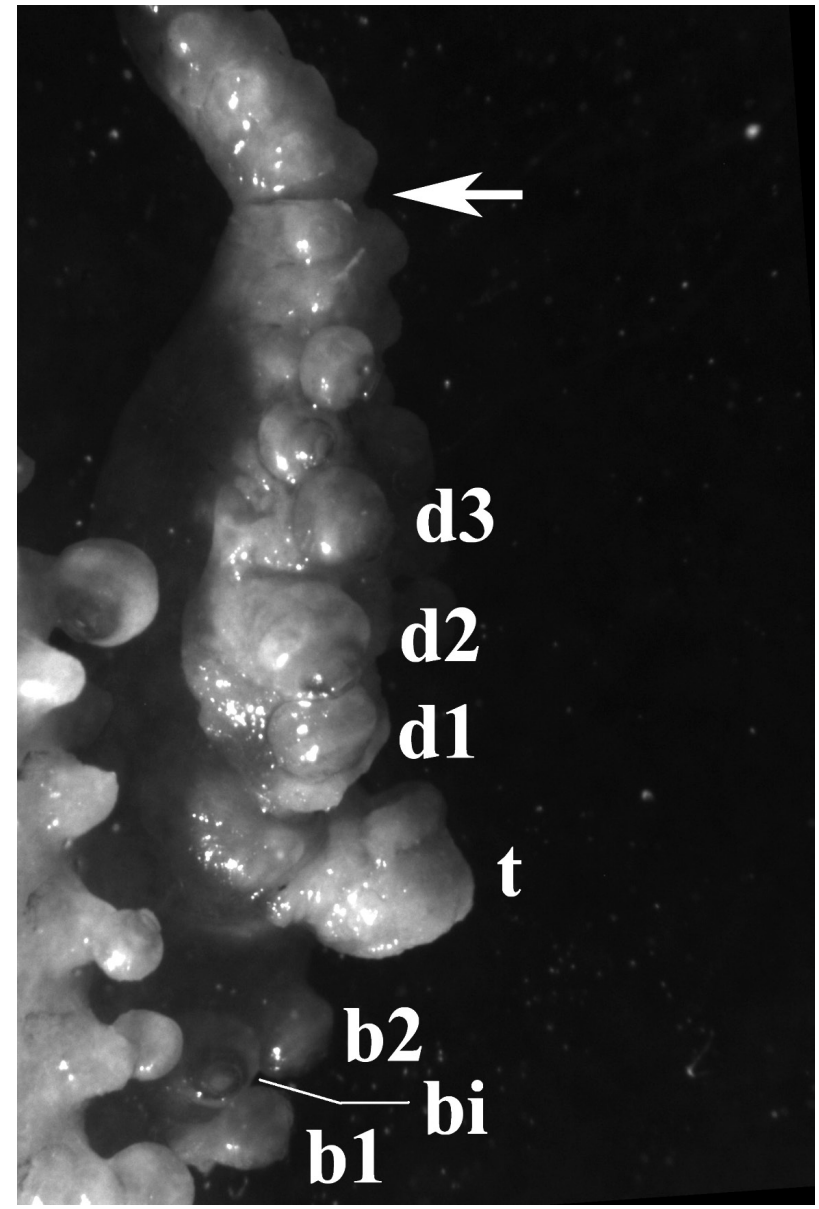

FIG. 11. - Inner lateral view of the hectocotylus of Sepiola bursadhaesa n. sp., paratype, MNCN 15.06/226P6, male. The arrow points to the semi-circular groove perpendicular to the arm axis separating the distalmost part of the hectocotylus from its proximal part; b1 and b2, first and second suckers, respectively, of the basal part ventral row; bi, sucker of the basal part dorsal row; $t$, tubercle of the copulatory apparatus; $\mathrm{d} 1, \mathrm{~d} 2$ and $\mathrm{d} 3$, first, second and third suckers, respectively, of the distal part dorsal row. 
TABLE 1. - Specimens of the type series; MNCN 15.06/226H is the holotype, all the others are paratypes. ML, dorsal mantle length; VML, ventral mantle length; TL, total length (less the tentacles); TL+t, total length with the tentacles; HW, head width.

\begin{tabular}{|c|c|c|c|c|c|c|c|}
\hline MNCN no. & $\operatorname{sex}$ & $\mathrm{ML}(\mathrm{mm})$ & VML (mm) & $\mathrm{TL}(\mathrm{mm})$ & $\mathrm{TL}+\mathrm{t}(\mathrm{mm})$ & HW (mm) & State of sexual maturity \\
\hline $15.06 / 226 \mathrm{H}$ & q & 18 & 16 & 42 & 48 & 13 & $\begin{array}{l}\text { Mature, copulated (spermatangia on the bursa } \\
\text { copulatrix) }\end{array}$ \\
\hline $15.06 / 226 \mathrm{P} 1$ & q & 24 & 21 & 51 & 72 & 15 & $\begin{array}{l}\text { Mature and full of eggs, copulated (spermatangia } \\
\text { on the bursa copulatrix) }\end{array}$ \\
\hline $15.06 / 226 \mathrm{P} 2$ & 우 & 22 & 20 & 49 & 57 & 15 & $\begin{array}{l}\text { Mature, copulated (mantle cavity full of } \\
\text { spermatophores; spermatangia all over external } \\
\text { surface of body and within mantle cavity, } \\
\text { including on the bursa copulatrix) }\end{array}$ \\
\hline $15.06 / 226 \mathrm{P} 3$ & q & 15 & 15 & 38 & 51 & 13 & Immature, virgin \\
\hline $15.06 / 226 \mathrm{P} 4$ & 产 & 24 & 23 & 56 & 68 & 17 & Mature \\
\hline $15.06 / 226 \mathrm{P} 5$ & $\hat{O}$ & 21.5 & 20 & 51 & 61 & 16 & Mature \\
\hline $15.06 / 226 \mathrm{P} 6$ & $\hat{\sigma}$ & 21.5 & 19 & 50 & 55 & 16 & Mature \\
\hline $15.06 / 226 \mathrm{P} 7$ & $\hat{\sigma}^{1}$ & 21 & 19 & 52 & 56 & 16 & Mature \\
\hline $15.06 / 226 \mathrm{P} 8$ & o & 22 & 20 & 55 & 59 & 17 & Mature \\
\hline $15.06 / 226 \mathrm{P} 9$ & $\hat{\sigma}$ & 19 & 17 & 52 & 63 & 16 & Mature \\
\hline
\end{tabular}

Remarks. As usual with the genus Sepiola, marked interspecific differences occur in the copulatory organs, namely the female bursa copulatrix and the male hectocotylus, which also in the present case distinguish Sepiola bursadhaesa $\mathrm{n}$. sp. from its congeners. More specifically, $S$. bursadhaesa n. sp. belongs to the $S e$ piola atlantica group as defined by Naef (1923), typified by the peculiar morphology of the male copulatory apparatus (see next paragraph for details). Within this group, S. affinis, S. intermedia and S. bursadhaesa $\mathrm{n}$. sp. make up a subgroup characterized by six rows of suckers on the tentacle club, a small bursa copulatrix in females, and the occurrence of a groove along the inner lateral side of the hectocotylus. Therefore, I shall compare $S$. bursadhaesa $\mathrm{n}$. sp. mainly with $S$. intermedia and S. affinis. Indeed, especially the male specimens of $S$. bursadhaesa n. sp. may be easily mistaken at first glance for $S$. intermedia because of their same general appearance and size and, most importantly, a somewhat similar hectocotylus. Sepiola affinis clearly differs because of the position of the enlarged suckers midway along the dorsal row of the distal part of the hectocotylus, which is very curved, in addition to its smaller body size. The females of $S$. bursadhaesa $\mathrm{n}$. sp., may also be confused with the two other species because of their velum, which may resemble the mantle constrictor of $S$. intermedia or the vestigial mantle constrictor of $S$. affinis. However, the fusion of the bursa copulatrix to the left side inner wall of the mantle is unique in the females of Sepiola bursadhaesa $\mathrm{n}$. sp. Incidentally, because of the firm attachment of the bursa to the mantle, when one cuts the mantle along its right side and turns it like a door to expose the mantle cavity, the posteriormost part of the bursa may break so that the split portion remains attached to the mantle (Figs 4 and 5). This happened in three out of the four examined females. Otherwise, the scar of the bursa attachment is clearly visible on the left inner face of the mantle (Fig. 6).

The differences between the hectocotylus of $S$. bursadhaesa n. sp. and S. intermedia are more subtle, but still unmistakable. The tubercle of the copulatory apparatus is quite different: in S. bursadhaesa n. sp. it is very wrinkled and variable in shape (Fig. 8) and is not roundish and smooth as in S. intermedia and, in addition, it projects freely outward more markedly. In S. bursadhaesa $\mathrm{n}$. sp. the enlarged suckers in the dorsal row of the distal part follow the pattern first enlarged, second very enlarged, third enlarged, whereas in $S$. intermedia the pattern is first very enlarged, second enlarged, so there is one more enlarged sucker in $S$. bursadhaesa $\mathrm{n}$. sp. Naef (1923) reported variability in the enlarged sucker pattern, which also included that displayed by $S$. bursadhaesa n. sp. described here. However, all the $S$. intermedia mature male specimens examined by the present author, consisting of many dozens from the Adriatic Sea and several more from other Mediterranean areas, including those kept in the MNCN, have only two enlarged suckers in the dorsal row of the distal part, the first the largest and the second a little smaller. The specimens examined by Naef (1923) may have included representatives of $S$. bursadhaesa $\mathrm{n}$. sp. and this would explain the observed variability. Furthermore, the $S$. intermedia hectocotylus does not bear a semi-circular groove perpendicular to the longitudinal arm axis, distal to the lateral groove; the constriction between the basal and distal parts of the hectocotylus is less marked in S. bursadhaesa $\mathrm{n}$. sp. than in S. intermedia; the dorsal row of the distal part bears more suckers in the former than in the latter species (14-16 vs. 11-12).

The attribution of the male and female specimens in the MNCN sample dealt with in the present paper to the same specific entity is supported by the identity of the male and female non-dimorphic characters, above all the tentacular club.

The type locality was recognized as the Catalan Sea because these sepiolines were acquired at the fish market in Barcelona in the first half of the 1930s (fide Oscar Soriano), at a time when the fish sold there was fished locally. Moreover, the one specimen of Sepietta obscura - a species quasi-endemic to the Mediterranean Sea that has never been caught in the Spanish Atlantic waters (Bello 2003)—collected together with 
TABLE 2. - Key characters of the species in the Sepiola atlantica group.

\begin{tabular}{|c|c|c|c|c|c|c|c|c|}
\hline Characters & affinis & atlantica & bursadhaesa & intermedia & robusta & rondeletii & steenstrupiana & tridens \\
\hline $\begin{array}{l}2^{\text {nd }} \text { and } 3^{\text {rd }} \text { stalks of the } \\
\text { hectocotylus dorsal row } \\
\text { form a conspicuous tubercle } \\
\text { curved towards the median side }\end{array}$ & + & + & + & + & + & + & - & + \\
\hline $\begin{array}{l}\text { presence of a few markedly } \\
\text { enlarged suckers in dorsal } \\
\text { row of the hectocotylus } \\
\text { distal part and their position }\end{array}$ & midway & $\begin{array}{l}2 \text { groups, } \\
\text { proximal } \\
\text { and midway }\end{array}$ & proximal & proximal & none & none & none & $\begin{array}{l}2 \text { groups, } \\
\text { proximal } \\
\text { and midway }\end{array}$ \\
\hline $\begin{array}{l}\text { inner lateral side of distal part of } \\
\text { hectocotylus with deep groove }\end{array}$ & + & - & + & + & - & - & - & - \\
\hline $\begin{array}{l}\text { heteromorphous tip of } \\
\text { ventral arms and number } \\
\text { of sucker longitudinal rows } \\
\text { in heteromorphous tip }\end{array}$ & - & $7-8$ & - & - & - & - & 4 & 6 \\
\hline $\begin{array}{l}\text { number of sucker rows } \\
\text { in tentacle club }\end{array}$ & 6 & 8 & 6 & 6 & 8 & 8 & $4-5$ & 6 \\
\hline
\end{tabular}

the type specimens strongly supports the assumption that the origin of these specimens is Mediterranean. The presence of $S$. obscura in the sample also suggests that the $S$. bursadhaesa n. sp. specimens were taken in coastal waters, i.e. where that Sepietta species lives preferentially (Reid and Jereb 2005). At the time of the sample collection, shallow water sepiolines were fished mainly by arte de playa, a trawl net no longer in use, which had one end fastened on the land and the other carried by a row boat first seaward and then landward in a broad arc (Pilar Sánchez, pers. comm.), again suggesting that a coastal habit is likely.

In summary, S. bursadhaesa n. sp. is the third species in the subgroup of Sepiola species with a laterally grooved hectocotylus. Because of its close similarities to $S$. intermedia, one may predict that these two sepiolines are sister species and that, possibly, S. bursadhae$s a$ n. sp. lives on shallower grounds than $S$. intermedia.

\section{Remarks on the Sepiola atlantica group}

The hectocotylus morphology of $S$. bursadhaesa n. sp., in addition to showing its close affinity with $S$. intermedia, places it in the Sepiola atlantica group as defined by Naef (1923); note that Naef did not grant any genus-group rank to this group. According to Naef (1923: 582), in the species of this group "the base of the hectocotylus bears 3 normal suckers, followed by a typical copulatory apparatus which develops from the stalks of 4 suckers, the $2^{\text {nd }}$ and $3^{\text {rd }}$ sucker of the median [i.e. dorsal] row and the $3^{\text {rd }}$ and $4^{\text {th }}$ of the lateral [i.e. ventral] row." These four suckerless stalks are enlarged and fused together to form a typical organ followed by the distal part of the arm that may bear some enlarged suckers in the dorsal row (Fig. 1). Naef (1923: 583) included in this group "all the Mediterranean species, except $S$. aurantiaca and $S$. ligulata, both of which show a different type of hectocotylization." Sepiola tridens de Heij and Goud, 2010, a recently described species, is also to be added to the atlantica group on the ground of its hectocotylus structure. All the remaining species of the genus Sepiola are excluded because of the different configuration of their hectocotylus. Hence, the atlantica group sensu Naef (1923) includes S. affinis, S. atlantica, S. bursadhaesa n. sp., S. intermedia, $S$. robusta, $S$. rondeletii, $S$. steenstrupiana and $S$. tridens. All of them live in the NE Atlantic-Mediterranean region. These species, sharing the synapomorphy of the peculiar copulatory apparatus, as described above, form a fairly compact monophyletic clade.

In order to appreciate the relationships within the group, some key characters are listed in Table 2; most autapomorphic characters of individual species are not reported there. According to such characters, S. steenstrupiana is singled out because of its copulatory apparatus without a tubercle, the reduced number of sucker rows on the tentacle club and the heteromorphous ventral arm tip. The latter character ostensibly associates this species with both S. atlantica and S. tridens. However, in addition to bearing a lower number of sucker rows, the heteromorphous arm tip of S. steenstrupiana is somewhat shorter than in the other two species, viz. well below $1 / 5$ of the arm length. In this regard, one may hypothesize an independent origin of this character in $S$. steenstrupiana, since the occurrence of a heteromorphous tip of the ventral arm pair alone is recorded in phylogenetically comparatively distant sepiolid taxa, such as the Heteroteuthinae (Naef 1923), which shows that sepiolids are genetically predisposed to this modification.

The subgroup of $S$. affinis, S. intermedia and $S$. bursadhaesa n. sp. is seemingly associated with $S$. atlantica and S. tridens, because of the enlargement of a few suckers of the dorsal row of the hectocotylus distal part. The last two species are evidently allied with each other (de Heij and Goud 2010). Indeed, S. atlantica bears 8 rows of suckers on the tentacle club, which sets it close to both $S$. robusta and S. rondeletii. Naef (1923) 
attributed a major phylogenetic meaning to the number of club sucker rows, but it must be admitted that this character is fairly variable in Sepiolinae; compare, for instance, the closely allied Sepietta oweniana and Sepietta neglecta, which bear 32 and 16 rows of suckers on tentacle clubs, respectively (Naef 1923). The relative positions of $S$. robusta and $S$. rondeletii appear to be basal with respect to the other species with a tubercle in the copulatory apparatus.

\section{Key to species in the Sepiola atlantica group}

1A. Tip of ventral arms normal, i.e. with 2 longitudinal rows of suckers. 2

1B. Tip of ventral arms heteromorphous with more than 2 longitudinal rows of suckers. 5

2A. Tentacle club with 8 rows of suckers. 3

2B. Tentacle club with 6 rows of suckers.

3A. つิ part; copulatory apparatus forms an eyelet; sucker rows of distal part with no space in between, those in the dorsal row slightly enlarged;

우: bursa copulatrix with small caecum on the right side of mantle cavity . S. rondeletii

3B. $\hat{\sigma} \widehat{T}$ : hectocotylus with markedly enlarged $2^{\text {nd }}$ sucker of ventral row; copulatory apparatus does not form an eyelet; suckers of both rows of distal part equally sized, with a space between rows proximally;

Q $O$ : bursa copulatrix without caecum on the right side of mantle cavity S. robusta

4A. $\widehat{\jmath}$ : dorsal row of hectocotylus distal part with $1^{\text {st }}$ sucker markedly enlarged and $2^{\text {nd }}$ enlarged; tubercle of copulatory apparatus roundish and little or not wrinkled;

우: bursa copulatrix independent from mantle inner surface, i.e. not fused with it; mantle constrictor on the posterior left side of mantle cavity, i.e. cutaneous muscle extending from the mantle septum to the base of left gill (a probe may be inserted between the cavity organs and the constrictor; cf. Bello 1995: Fig. 5 9 A)....................... intermedia

4B. $\delta^{\lambda}$ : dorsal row of hectocotylus distal part with $1^{\text {st }}$ sucker enlarged, $2^{\text {nd }}$ markedly enlarged, $3^{\text {rd }}$ enlarged; tubercle of copulatory apparatus very wrinkled and variable in shape, usually not roundish, with free portion projecting markedly outward;

$q \bigcirc$ : entire posterior rim of bursa copulatrix fused to inner surface of mantle, posterior to gill septum; no mantle constrictor, but a thin transparent velum on posterior part of ventral surface of mantle organs S. bursadhaesa n. sp.

4C. $\hat{\sigma} \hat{o}$ : hectocotylus distal part with 3-4 markedly enlarged suckers in middle of dorsal row; 우: bursa copulatrix independent from mantle inner surface, i.e. not fused with it; no well-developed mantle constrictor on the posterior left side of mantle cavity (a vestige of it may be present). S. affinis

5A. Tip of ventral arms with 4 longitudinal rows of suckers; heteromorphous tip length shorter than $1 / 5$ of arm length; tentacle club with 4-5 rows of suckers ...........................................S. steenstrupiana

5B. Tip of ventral arms with 6-8 longitudinal rows of suckers; heteromorphous tip length 1/5 of arm length or longer; tentacle club with 6 or more rows of suckers. 6

6A. Tentacle club with 8 rows of suckers; ô: dorsal row of hectocotylus distal part with 3-4 markedly enlarged suckers in middle part (in addition to the proximal enlarged suckers); 오: bursa copulatrix with small extension towards left gill (cf. de Heij and Goud 2010: Fig. 6) S. atlantica

6B. Tentacle club with 6 rows of suckers; oิ $\sigma^{\lambda}$ : dorsal row of hectocotylus distal part with 5-8 markedly enlarged suckers in middle part (in addition to the proximal enlarged suckers); 우: bursa copulatrix with large extension towards left gill (cf. de Heij and Goud 2010: Fig. 6).... S. tridens

\section{DISCUSSION}

The description of Sepiola bursadhaesa n. sp. increases to 11 the number of NE Atlantic-Mediterranean species of Sepiola, thus providing further evidence of high diversity among the NE Atlantic-Mediterranean sepiolines. This new species is seemingly endemic to the Mediterranean and its discovery reinforces the statement by Mangold and Boletzky (1988: 326) that, "It is interesting that the only cephalopod species exclusively known from the Mediterranean are among the Sepiolinae". Indeed, all or almost all Mediterranean species in the genus Sepiola are endemic or quasiendemic (a term used by Bello (2003) merely to distinguish the species found in the near Atlantic Ocean outside the Strait of Gibraltar from the truly Mediterranean endemic); on the other side of the Strait, the NE Atlantic Sepiola species are also endemic to that area (cf. Bello 2003, Groenenberg et al. 2009, de Heij and Goud 2010). In my opinion, the causes underlying the many cases of endemism in Sepiola are the same as those that have favoured speciation in these animals, viz. their small body size; fairly diverse copulatory organs in males (hectocotylus) and, less conspicuously, in females (bursa copulatrix); the small number of eggs and, hence, fecundity; the production of comparatively large eggs and hatchlings that immediately adopt a benthic rather than planktonic lifestyle (Boletzky 1974, 1977); a nekto-benthic mode of life; a short life cycle (less than a year) (Boletzky 1975); and their preference for shallow depths. See Boletzky (1999) and Bello (2003) for further discus- 
sion. To conclude, it can be hypothesized that the NE Atlantic-Mediterranean species of Sepiola are a suite of species that largely arose from in situ speciation on either side of the Strait of Gibraltar after the vicariant event(s) of (recurring) connection to the Atlantic and isolation of the Mediterranean.

Because of the abovementioned combination of factors that facilitates speciation, it is likely that other, still undescribed species of this genus await discovery. In fact, when one looks back to the history of the description of NE Atlantic-Mediterranean sepiolines, only one century ago Naef (1912a, 1912b, 1916, 1923) recognized their high diversity in a comparatively small geographic area. This late discovery was caused by the quite uniform bauplan of the different species. This initially misled researchers and few species were recognized. Some of these are now even assigned to different genera, namely Sepiola, Sepietta and Rondeletiola. This same reason caused much confusion in nomenclature and classification (e.g. Groenenberg et al. 2009, Bello 2011, Goud and de Heij 2012). For instance, the recently described Sepiola tridens was discovered thanks to modern genetic techniques (Groenenberg et al. 2009) and only afterwards was discriminated morphologically from its sibling species, $S$. atlantica. Only subtle differences separate these two taxa (de Heij and Goud 2010).

In the case of $S$. bursadhaesa n. sp., the original description of $S$. intermedia provided by Naef (1912b) may be misleading. In describing the hectocotylus, Naef (1923: 600) wrote, "The suckers in the distal part of the arm vary in size, particularly in the inner [viz. dorsal] row. The basal [viz. copulatory] apparatus is followed either by 2 markedly enlarged suckers, of which the proximal is slightly larger, or by 3 enlarged suckers, of which the median is the largest, or by a very small sucker, then a very large and then a moderately large sucker." The latter two variations have never been observed by myself, or seemingly by other collegues (e.g. for the Catalan Sea: Wirz 1958, Sánchez and Morales 1986), since all specimens identified as S. intermedia bore only two large suckers, the first very large and the second one not as large, followed by regular size suckers tapering distally to the arm tip. As reported in the Results section, the specimens examined by Naef (1923) may have included representatives of $S$. bursadhaesa n. sp. or yet undescribed species, thus explaining the observed variability.

To conclude, it must be stressed that the collection of additional specimens of S. bursadhaesa n. sp. is necessary to define both its typical habitat and its depth range.

As for the phylogenetic relationships among the members of the $S$. atlantica group, molecular analyses would be of great support for corroborating them. Unfortunately, the present situation as portrayed by the results available in GenBank is quite cloudy (Groenenberg et al. 2009), suggesting the need for additional analyses on properly identified material.

\section{ACKNOWLEDGEMENTS}

I am most grateful to José Templado (MNCN, Madrid) for inviting me to examine the cephalopod collection of the Museum and facilitating my visit there within the programme BIOD-IBERIA, to Oscar Soriano (former curator of the molluscan collection, MNCN, Madrid) for the information about the sample of the historical collection containing the new species, and to Rafael Araujo (present curator of the molluscan collection, MNCN, Madrid) for his patience and support. I am deeply obliged to Rushan Sabirov and Arseniy Morov (Department of Invertebrate Zoology and Functional Histology, Kazan Federal University), who tirelessly attempted the impossible task of obtaining suitable results from molecular-genetic analyses of the Sepiola bursadhaesa specimens. I also thank Aldo Corriero and Rosa Zupa (Department of Emergency and Organ Transplant, University of Bari) for their hospitality and assistance with the photographs, Pilar Sánchez (Institut de Ciències del Mar, Barcelona) for the information on arte de playa, and Rafael La Perna (Department of Geology and Geophysics, University of Bari) for suggestions concerning the International Code of Zoological Nomenclature. My warmest thanks to Amanda Reid (Australian Museum, Sydney) for critically reading a first version of this paper and for thoroughly reviewing it, to Chung-Cheng Lu (Department of Life Sciences, National Chung Hsing University, Taichung, Taiwan) for reviewing the submitted MS and providing several suggestions, and to an anonymous referee for his/her advice. I also thank Anthony Green (University of Bari) for kindly reviewing the English in the manuscript.

\section{REFERENCES}

Bello G. 1995. A key for the identification of the Mediterranean sepiolids. Bull. Inst. Océanogr. Monaco nº spéc. 16: 41-55.

Bello G. 2003. The biogeography of Mediterranean cephalopods. Biogeographia 33: 209-226.

Bello G. 2011. Invalidity of the nominal species Sepietta petersii (Steenstrup 1887) and nomenclatural revision of the genus Sepietta Naef 1912 (Cephalopoda: Sepiolidae). J. Conchol. 40: 549-558.

Bizikov V.A. 2008. Evolution of the shell in Cephalopoda. VNIRO Publishing, Moscow, 448 pp.

Boletzky S.v. 1974. The "larvae" of Cephalopoda: a review. Thalassia Jugoslavica 10: 45-76.

Boletzky S.v. 1975. The reproductive cycle of Sepiolidae (Mollusca, Cephalopoda). Pubbl. Staz. Zool. Napoli 39 suppl.: 84-95.

Boletzky S.v. 1977. Post-hatching behaviour and mode of life in cephalopods. Symp. Zool. Soc. London 38: 557-567.

Boletzky S.v. 1999. Biologie et biogéographie des céphalopodes actuels. Bull. Soc. Géol. France 170: 205-215.

Clarke M.R. 1986. A Handbook for the Identification of Cephalopod Beaks. Clarendon Press, Oxford, xiii +273 pp.

Folmer O., Black M., Hoeh W., Lutz R., Vrijenhoek R. 1994. DNA primers for amplification of mitochondrial cytochrome c oxidase subunit I from diverse metazoan invertebrates. Mol. Mar. Biol. Biotechnol. 3: 294-299.

Goud J., de Heij A. 2012. Nederlandse fauna: Sepietta oweniana eruit. Rondeletiola minor nog niet erin! Spirula 385: 54-55.

Groenenberg D.S.J., Goud J., de Heij A., Gittenberger E. 2009. Molecular phylogeny of North Sea Sepiolinae (Cephalopoda: Sepiolidae) reveals an overlooked Sepiola species. J. Molluscan 
Stud . 75: 361-369.

Heij A. de, Goud J. 2010. Sepiola tridens spec. nov., an overlooked species (Cephalopoda: Sepiolidae) living in the North Sea and north-eastern Atlantic Ocean. Basteria 74: 51-62.

Mangold K., Boletzky S.v. 1988. Mediterranean Cephalopod Fauna. In: Clarke M.R., Trueman E.R. (eds.), The Mollusca, 12, Pale ontology and Neontology of Cephalopods. Academic Press, London and New York, pp. 315-330.

Naef A. 1912a. Teuthologische Notizen. 3. Die Arten der Gattungen Sepiola und Sepietta. Zool. Anz. 39: 262-271.

Naef A. 1912b. Teuthologische Notizen. 7. Zur Morphologie und Systematik der Sepiola- und Sepietta-Arten. Zool. Anz. 40: 78-85.

Naef A. 1916. Ueber neue Sepioliden aus dem Golf von Neapel. Pubbl. Staz. Zool. Napoli 1: 1-10.

Naef A. 1923. Die Cephalopoden. Fauna Flora Golf. Neapel 35(I,
1): 863 pp. [English translation by A. Mercado, 1972; Smithsonian Institution, Washington D.C.]

Reid A., Jereb P. 2005. Family Sepiolidae. In: Jereb P., Roper C.F.E. (eds.), Cephalopods of the World. An annotated and illustrated catalogue of species known to date. FAO Species Cat. Fish. Purposes 4(1): 153-203.

Sánchez P., Morales E. 1986. Nota sobre la presencia de cuatro especies de Sepiolidae (Mollusca: Cephalopoda) en el Mediterráneo noroccidental español. Inv. Pesq. 50: 137-144.

Wirz K. 1958. Céphalopodes. Fauna Mar. Pyrénées-Orientales 1: 5-59.

Scient. ed.: R. Villanueva.

Received September 6, 2012. Accepted May 2, 2013.

Published online May 31, 2013. 